\title{
QUALITATIVE ANALYSIS METHOD OF DETECTION OF WAX CONTENT IN GORENGAN USING SMARTPHONE
}

\section{METODE ANALISIS KUALITATIF DETEKSI KANDUNGAN LILIN PADA GORENGAN MENGGUNAKAN SMARTPHONE}

\author{
Yulia $^{1}$, Hendri Wasito ${ }^{1 *}$, Amin Fatoni $^{2}$ \\ ${ }^{1}$ Department of Pharmacy, Faculty of Health Sciences, Jendral Soedirman University, Jalan Dr. \\ Soeparno Karangwangkal, Purwokerto, 53123, Indonesia \\ ${ }^{2}$ Department of Chemistry, Faculty of Mathematics and Natural Science, Jendral Soedirman \\ University, Jalan Dr. Soeparno Karangwangkal, Purwokerto, 53123, Indonesia
}

Received April 10, 2018; Accepted April 21, 2018

\begin{abstract}
Wax is one of the compounds that can be misused to be added to Gorengan, Indonesian fritter, to keep them crispy. Gorengan containing wax is difficult to identify visually, so a quick and easy method of detecting wax content is required. The purpose of this research is to develop and evaluate the analytical performance of detecting wax content in gorengan using smartphone. Gorengan sample was dissolved with hexane and then added reagent that will give discoloration followed by analysis using smartphone. Some analysis performance parameters were evaluated in terms of linearity and detection limit, qualitative analysis capability, precision, and selectivity test. The developed method was also applied in some gorengan samples. The result shows that the detection of wax content in gorengan can be conducted by using reagent consisting of $\mathrm{NaOH}$, Schift, and curcumin $(1: 2: 2)$. Performance analysis shows that the linearity measurement at concentration between $10 \%$ and $25 \%$ has correlation coefficient $(r)$ of 0.9537 with detection limit at concentration of $2 \%$ and precision (\%RSD) less than 3\%. The developed method can be applied for the detection of wax content in gorengan in the market.
\end{abstract}

Keywords: analysis, chemometrics, gorengan, smartphone, wax

\begin{abstract}
ABSTRAK
Lilin merupakan salah satu bahan yang dapat disalahgunakan untuk ditambahkan pada gorengan agar tetap renyah. Gorengan yang mengandung lilin sulit untuk diidentifikasi secara visual, sehingga diperlukan metode deteksi kandungan lilin yang cepat dan mudah. Tujuan penelitian ini adalah untuk mengembangkan dan menguji kinerja metode analisis kandungan lilin dalam gorengan secara kolorimetri menggunakan smartphone. Penelitian ini merupakan penelitian eksperimental menggunakan gorengan sebagai objek penelitian. Gorengan dilarutkan dengan heksan dan kemudian ditambahkan reagen yang akan memberikan perubahan warna yang selanjutnya dapat dianalisa menggunakan aplikasi smartphone. Beberapa parameter kinerja analisis dievalusi meliputi uji linearitas dan batas deteksi, uji kemampuan analisis secara kualitatif, uji presisi, serta uji selektifitas. Metode yang dikembangkan juga diaplikasikan untuk mendeteksi kandungan lilin pada beberapa sampel gorengan yang dijual di masyarakat. Hasil penelitian menunjukkan bahwa deteksi kandungan lilin dalam gorengan dapat dilakukan dengan menggunakan reagen yang terdiri dari NaOH, Schift, dan kurkumin $(1: 2: 2)$. Kinerja analisis metode yang dikembangkan menunjukkan bahwa linearitas pengukuran pada konsentrasi lilin $10 \%$ hingga $25 \%$ memiliki nilai koefisien korelasi (r) 0,9537 dengan nilai batas deteksi $2 \%$

*Corresponding author: Hendri Wasito

Email: hendri.apt@gmail.com
\end{abstract}


dengan nilai presisi (\%RSD) kurang dari 3\%. Metode yang dikembangkan dapat diaplikasikan untuk deteksi kandungan lilin pada sampel gorengan di pasaran.

Kata kunci: analisis, kemometrika, gorengan, smartphone, lilin

\section{INTRODUCTION}

Gorengan, Indonesian fritter, is one of the favorite snacks among the Indonesia society. Gorengan can be bought easily because it is widely sold in the roadside (Chalid et al., 2008). The people like to eat gorengan because of its savory and crispy taste as well as cheap price. The increasing fondness of eating gorengan causes the high competition among gorengan vendors. This situation sometimes causes the vendors to sell only some portions of their gorengan product in one day. This problem certainly triggers the loss among the gorengan vendors and some of them try to find a way to keep their gorengan crispy and delicious eventhough it is stored for days. One of the ways is misusing of candle as food additives. Candle contains paraffin wax and others additives (Rezaei et al., 2002). The gorengan vendors deliberately add wax in a heated cooking oil when frying gorengan. The mixture of wax in heated cooking oil affects the crispy taste of gorengan. Wax is not a food additive and it is difficult to be broken down by enzymes in human body. Therefore, when wax is consumed, it can harm human's digestive function and cause health problems (Griffis et al., 2010; Derudi et al., 2014; Sølling et al., 2018).

The content of wax in gorengan is difficult to identify visually. The analysis method of wax identification that is commonly used is gas chromatography associated with Mass Spectrometry, Near-infrared spectrometer (Palou et al., 2014), Differential Scanning Calorimetry (Chen et al., 2004; Kök et al., 2007), High-performance Liquid Chromatography (Moreau et al., 2002), and Thin-layer Chromatography (Lu et al., 2008). These methods require expensive and complex equipment, detailed preparation and particular skill on its implementation. Therefore, it is necessary to develop a simpler, cheaper, easier and more practical identification technique. A simple analysis technique commonly used in identifying a candle containing paraffin wax as the main compound is by using spot test analysis (Jungreis, 2004). Spot test analysis can be done by adding a particular reagent on the sample or by immobilizing the reagent in a membrane on the test strip and then the result is evaluated by identifying the discoloration (Ngom et al., 2010; Sutrisno et al., 2017).

The technology development has transformed smartphone not only to be a communication tool but also to be one of the identification tools of a compounds based on the color analysis of a figure or a sample. Smartphone is used in several studies as an analytical tool, such as detection of alcohol concentrations in saliva (Jung et al., 2015), detection of thiosulfate compounds using silver nanoparticles (Dong et al., 2017), formaldehyde measurement compounds in air (Yang et al., 2016), and others examinations. The potential use of smartphone for wax content detector in gorengan is important to be used by combining qualitative analysis of wax content based on the discoloration and the smartphone as the detector. This research aims to develop and examine methods of detection of wax content in gorengan by using smartphone. In addition, this research also aims to apply the developed method for qualitative analysis of wax content in gorengan sold in the market.

\section{METHODS}

\section{Materials}

The materials used in this research were candle, cooking oil, gorengan, aquadest, curcumin. The solvent and chemical compounds with pro-analysis quality were nhexane, ethanol, $\mathrm{NaOH}, \mathrm{NaNO}_{2}, \mathrm{NaHCO}_{3}$, Schiff's reagent (Merck Darmstadt, Germany). 


\section{Instrumentation}

The equipment used in this research were plat TLC Silica Gel GF 254 (Merck, Germany), TLC Chamber, capillary tube, vortex, micropipette $100 \mu \mathrm{L}-1000 \mu \mathrm{L} \quad$ (Eppendorf, Germany), and 8 MP Smartphone camera (Oppo, China) with android operation of 5.1 ROI 32 x 32 pixel with PhotoMetrix ${ }^{\circledR}$ Figure analysis application version 1.2.1 (Ghelfer.net Inc., Brazil).

\section{Selection and Optimization of Reagents}

The reagent in this research was curcumin $0.5 \%, \mathrm{NaOH} 10 \%$, Schift, $\mathrm{NaNO}_{2}$ $0.1 \%$ and $\mathrm{NaHCO}_{3} 5 \%$ which were examined either single or multiple reagent combination. The test was conducted by dissolving wax in 2 $\mathrm{mL}$ of cooking oil that had been heated and then adding $n$-hexane solvent. As the negative control, the mixture of heated cooking oil and n-hexane solvent was used. On each oil solution, $500 \mu \mathrm{L}$ of reagent was added and mixed to be homogeneous, then, the discoloration on each tube was observed. The selected reagent was a reagent giving clear discoloration when it was reacted. The selected reagent was then optimized in the form of volume of reagent and wax concentration in cooking oil in which the discoloration was observed as the next step. The test was conducted by dissolving wax in heated cooking oil and then adding n-hexane solvent and reagent. The most optimum reagent was the reagent giving proportional discoloration with the wax concentration added in cooking oil. It could be seen from the correlation coefficient $(r)$ approaching \pm 1 and providing clear and stable discoloration when it was analyzed in univariate analysis by using Photometrix ${ }^{\circledR}$ application on smartphone.

\section{Performance Test of Wax Analysis Method with Smartphone}

Several performance tests of analysis method that were conducted are linearity test and detection limit, ability test in qualitative analysis, precision test, and selectivity test. Linearity test and detection limit were conducted by making seven concentrations of wax solution in cooking oil with the concentration of $1 \%$ to $25 \%$ with each three times replication. Two $\mathrm{mL}$ of wax solution from the cooking oil was poured into test tube containing $3 \mathrm{~mL}$ of $\mathrm{n}$-hexane and $500 \mu \mathrm{L}$ of reagent, and then, it was homogenized by using vortex. The colors formed were observed, captured by using Photometrix ${ }^{\circledR}$ application on smartphone, and analyzed through univariate analysis. The detection limit was calculated using linearity data based on the value of three times the residual deviation standard.

The test of method capability in qualitative analysis was conducted by examining the ability of analysis method in grouping cooking oil solution containing wax with different concentrations. In addition, the discoloration observation and capturing the figure by using smartphone was also conducted. Afterwards, it was analyzed through univariate analysis by using Photometrix $^{\circledR}$ application. The precision test was conducted on self-made gorengan samples which is added with wax concentration of $0 \%, 5 \%$ and 10\%. Each sample was replicated eight times. The sample was grinded and filtrated. Two $\mathrm{mL}$ of the sample was taken and it was mixed with $3 \mathrm{~mL}$ of $\mathrm{n}$-hexane and $500 \mu \mathrm{L}$ of reagent. Its discoloration was observed and the pixel value detected by Photometrix ${ }^{\circledR}$ application was evaluated. The calculation of \%RSD was also conducted. Selectivity test was done by comparing cooking oil with $5 \%$ of wax concentration then fried dough was added. After it was prepared and reacted with reagent, the discoloration was observed and analyzed through univariate analysis using Photometrix ${ }^{\circledR}$ application. Afterwards, the calculation of measured wax content was done. The result was compared to the analysis of one-way ANOVA.

\section{Application Method on Gorengan Sample}

The developed method was applied to identify wax content on several samples of gorengan sold by vendors which were randomly picked in the market. The types of gorengan analyzed in this research were fried tofu, fried tempe, fried banana, fried sweet 
potato and bakwan (vegetables fritter snack). The samples of gorengan were prepared with n-hexane solvent and analyzed by adding $500 \mu \mathrm{L}$ of reagent and subsequently observed. The Figure was camptured by smartphone. A multivariate analysis using Photometrix ${ }^{\circledR}$ application was conducted to each sample of gorengan in order to identify the sample classification into four groups; gorengan not containing wax, gorengan with low wax content, gorengan with medium wax content, gorengan with high wax content. The identification result of wax content in gorengan was then compared to TLC method using eluent of benzene : methanol (2.4:0.1).

Table I. The Result of Reagent Optimization for Wax Content Analysis in Cooking Oil

\begin{tabular}{|c|c|c|c|c|c|c|c|}
\hline \multicolumn{4}{|c|}{ Ratio of Reagent Volume Variation } & \multirow{2}{*}{\multicolumn{4}{|c|}{$\begin{array}{l}\text { The color formed on the } \\
\text { wax concentration in } \\
\text { cooking oil }\end{array}$}} \\
\hline \multirow{2}{*}{$\begin{array}{l}\text { Curcumin } 0,5 \% \\
(\mu \mathrm{L})\end{array}$} & \multirow{2}{*}{$\begin{array}{l}\text { Schift } \\
(\mu \mathrm{L})\end{array}$} & \multirow{2}{*}{$\begin{array}{l}\mathrm{NaOH} 10 \% \\
(\mu \mathrm{L})\end{array}$} & \multirow{2}{*}{$\mathrm{r}$} & & & & \\
\hline & & & & $0 \%$ & $1 \%$ & $10 \%$ & $20 \%$ \\
\hline 1 & 1 & 1 & -0.784 & & & & \\
\hline 2 & 2 & 1 & 0.981 & & & & \\
\hline
\end{tabular}

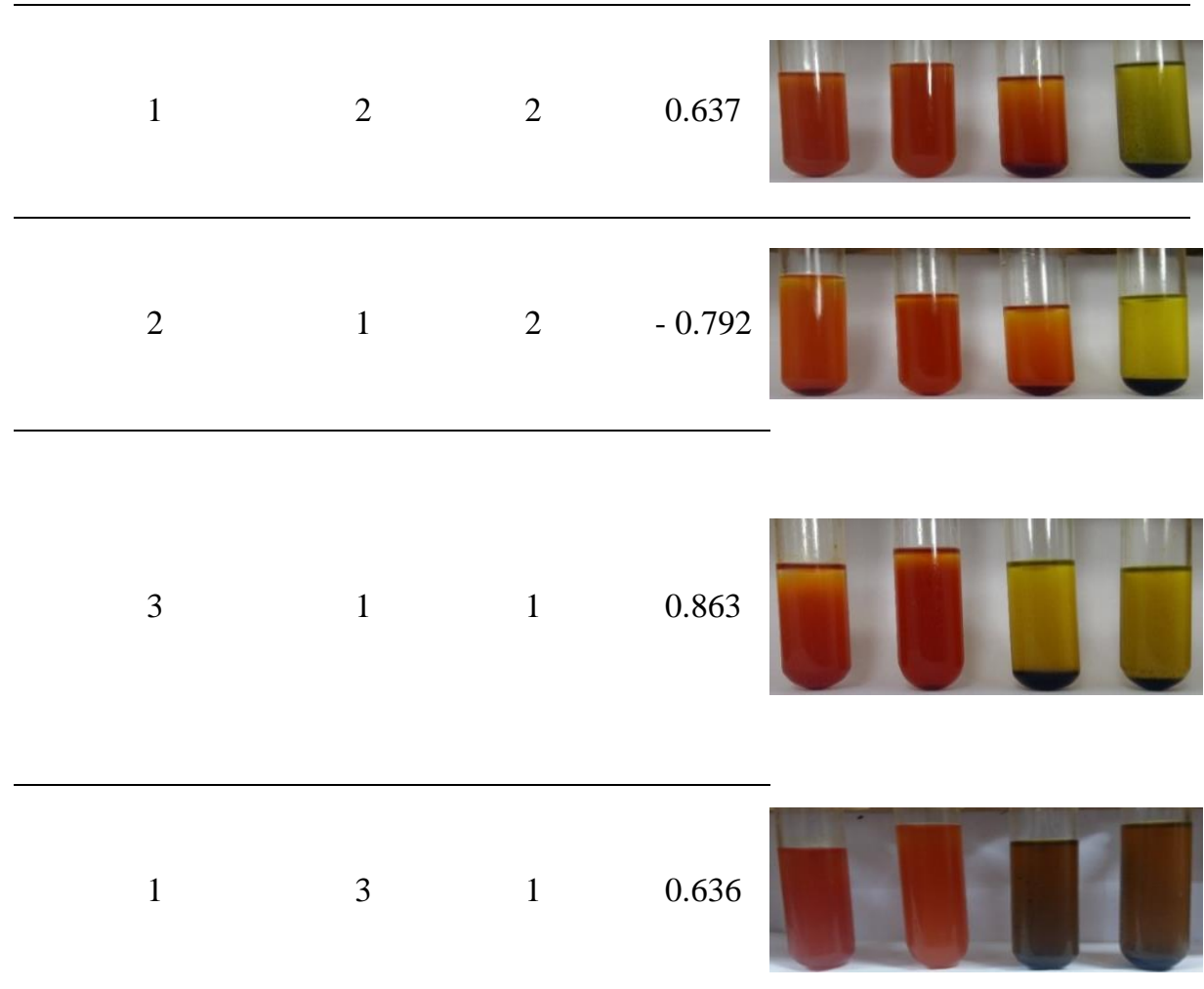


RESULTS AND DISCUSSION

\section{The Result of Selection and Optimization of Reagent}

The examination result on several reagent which were examined either single or multiple reagent combination of curcumin $0.5 \%, \mathrm{NaOH}$ $10 \%$, Schiff, $\mathrm{NaNO}_{2} 0.1 \%$ and $\mathrm{NaHCO}_{3} 5 \%$ shows that optimal reagent can produce clear discoloration. Curcumin in the alkaline condition has a red colour (Bernabé-Pineda et al., 2004). After Schiff reagent was added, it strengthens the colour that is formed into a reddish blue. The presence of wax content will cause saponification reaction with $\mathrm{NaOH}$. Therefore, it does not react to curcumin and will result curcumin reagent solution with yellow base. It is mixed with the reddish blue of Schiff reagent then resulting more concentrated green. Optimization of reagent is conducted in order to obtain reagent that can provide clearer and more stable discoloration. Optimization of reagent can be conducted by varying concentrations of curcumin, $\mathrm{NaOH}$, and Schiff. The result of optimization of reagent is presented in Table I.

Based on the observation result of discoloration, there are selected ratios of reagent; curcumin $0.5 \%$, Schiff $200 \mu \mathrm{L}$ and
$\mathrm{NaOH} 10 \%$ (2:2:1). The ratio selection causes clearer and more stable discoloration after adding cooking oil containing wax and dissolved in an n-hexane solvent. The optimization of reagent is also based on the correlation coefficient $(r)$ evaluated with univariate analysis. $G$ channel on Photometrix $^{\circledR}$ application is selected as measurement channel because it has $r$ value approaching \pm 1 . This shows relationship between wax concentrations in cooking oil with color intensity that is produced (Helfer $e t$ al., 2017).

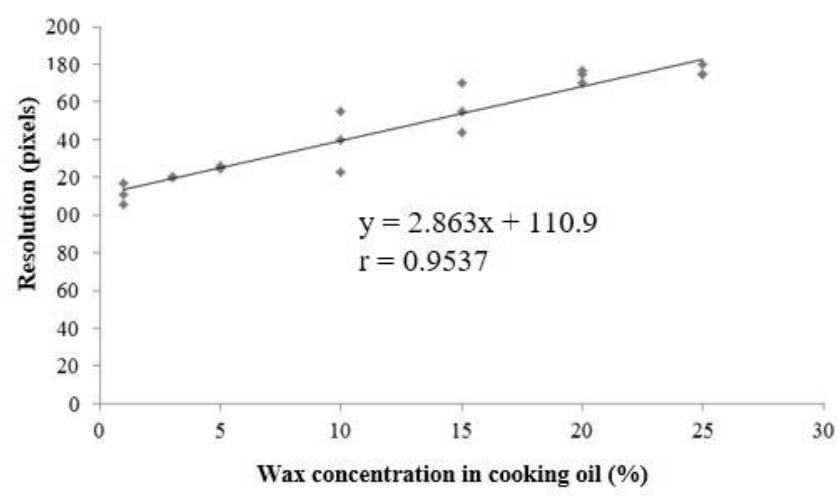

Figure 1. Linearity measurement of wax analysis in cooking oil using smartphone method

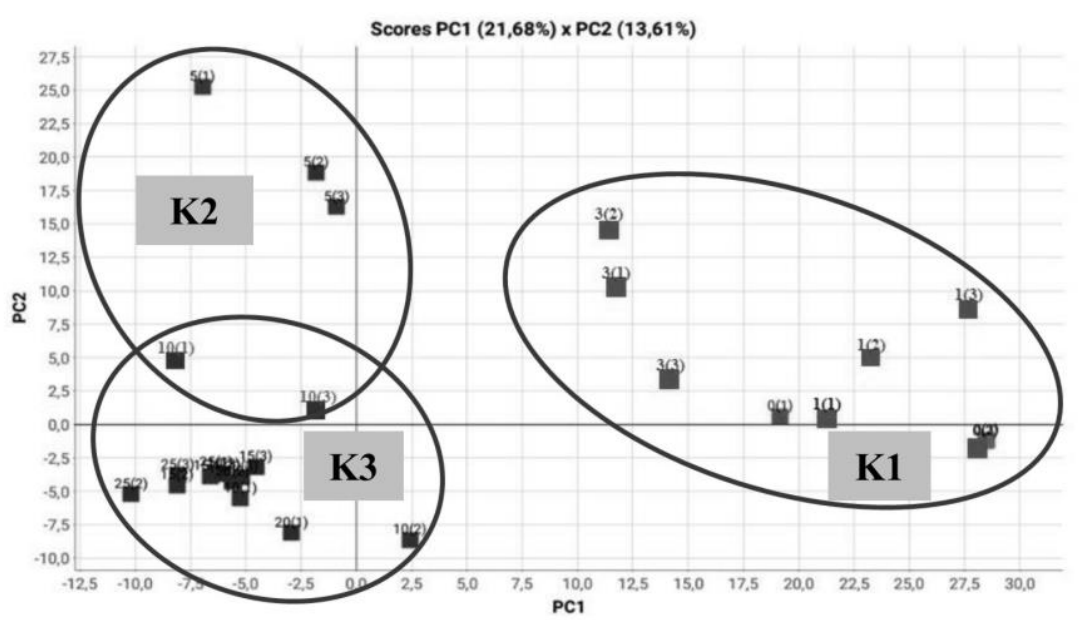

Figure 2. The analysis result of multivariative score plot of wax concentration using Photometrix ${ }^{\circledR}$ application 


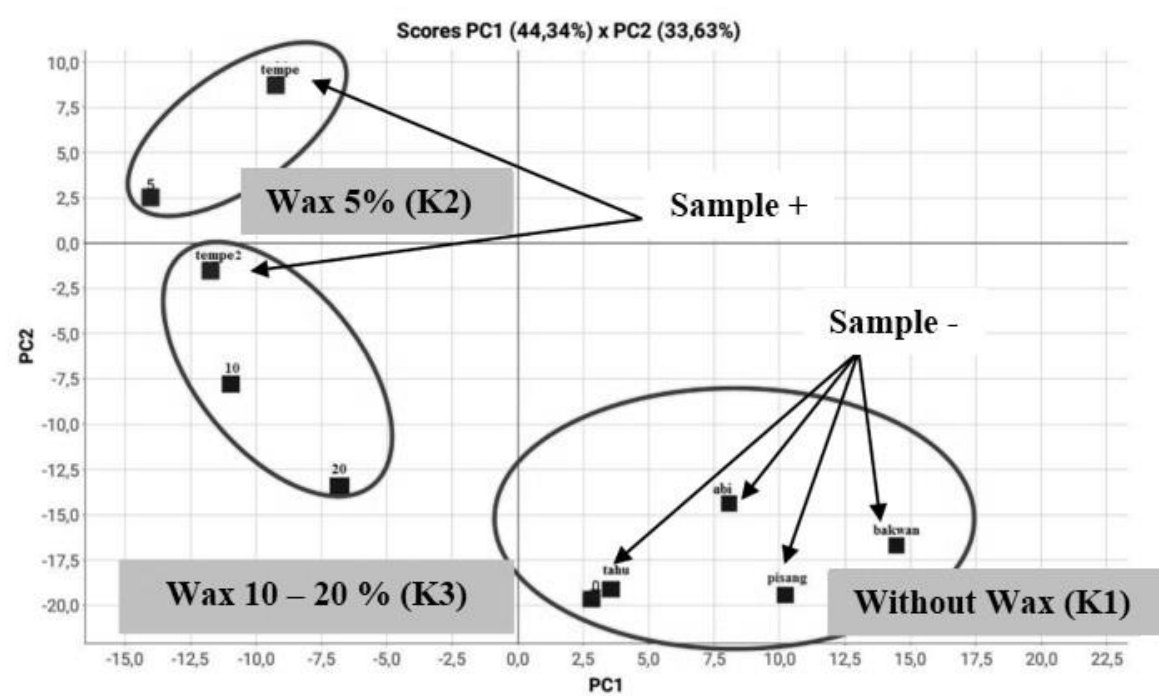

Figure 3. The result of score plot of wax content detection analysis of gorengan sample in the market using multivariate analysis and Photometrix ${ }^{\circledR}$ application on smartphone

\section{The Result of Wax Analysis Method by Using Smartphone.}

The result of linearity measurement of wax analysis in cooking oil was conducted to seven different wax solutions with $1 \%$ until $25 \%$ concentration detected by smartphone presented in Figure 1. Linear regression equation obtained is $\mathrm{y}=2.863 \mathrm{x}+110.9$ with correlation coefficient of $r=0.9537$. The higher wax concentration in cooking oil will provide response analysis of color resolution recorded by smartphone presented in a proportional pixel unit. The calculation of detection limit by residual standard deviation method shows that wax concentration in cooking oil can still be detected by the developed method; $2.14 \%$.

Qualitative analysis of the classification of wax sample in cooking oil with different concentration was conducted by multivariate analysis. This analysis helps to find out whether the wax which has similar concentration will be classified based on its classification. The classification test was conducted by using Principal Component Analysis (PCA). The variable category is the difference of wax concentration and evaluation on score plot presented in Figure 2. The result of score plot shows that the first and the second field has a total variability of
35.29\%. PC1 and PC2 provide visualization of the separation among wax sample cassifications in cooking oil with different concentration qualitatively. PC2 with $13.61 \%$ from the total variance is able to identify a sample into three groups; K1, K2 and K3. The first group, K1, consists of wax sample with concentration of $0 \%, 1 \%$ and $3 \%$. The concentration in wax sample of $\mathrm{K} 2$ are $5 \%$ and $10 \%$. While on $\mathrm{K} 3$, the concentration of wax sample are $10 \%, 20 \%$ and $25 \%$. Due to the difference of quadrant position among wax with similar concentration, then PC selected horizontally able to separate among the groups. From the several PCs, PC1 with $21.68 \%$ of the total variance shows good result in separating among groups. $\mathrm{K} 1$ is on the positive side, $\mathrm{K} 2$ and $\mathrm{K} 3$ are on the negative side. However, $\mathrm{K} 1$ with $3 \%$ of wax concentration shows a tendency to approach the negative side. It is because the detection limit of this method is $2.14 \%$. it can be concluded that PC1 and PC2 are proved to be able to classify wax standard based on the concentration. $\mathrm{K} 1$ is a group of wax standard with low concentration. $\mathrm{K} 2$ is a group of wax standard with medium concentration. While $\mathrm{K} 3$ is a group of wax standard with high concentration. 
Table II. The Result of Precision Test of Analysis Method on Wax Concentration of 5\% and 10\%

\begin{tabular}{cccc}
\hline Sample & $\begin{array}{c}\text { Concentration of } 0 \% \\
\text { (pixel) }\end{array}$ & $\begin{array}{c}\text { Concentration of } 5 \% \\
\text { (pixel) }\end{array}$ & $\begin{array}{c}\text { Concentration of } 10 \% \\
\text { (pixel) }\end{array}$ \\
\hline 1 & 97.50 & 125.00 & 135.00 \\
2 & 102.50 & 128.00 & 138.10 \\
3 & 102.00 & 128.00 & 133.50 \\
4 & 95.00 & 125.00 & 141.10 \\
5 & 97.50 & 125.10 & 137.00 \\
6 & 97.00 & 127.00 & 141.00 \\
7 & 96.50 & 126.00 & 141.20 \\
8 & 100.00 & 124.50 & 133.50 \\
\hline Average & 98.50 & 126.07 & 137.55 \\
SD & 2.70 & 1.41 & 3.33 \\
$\%$ RSD & 2.74 & 1.10 & 2.40 \\
\hline
\end{tabular}

Table III. The Measurement Result on the Level of Wax Content in Cooking Oil Before and After Adding the Flour

\begin{tabular}{ccc}
\hline \multirow{2}{*}{$\begin{array}{c}\text { Wax Concentration } \\
(\%)\end{array}$} & \multicolumn{2}{c}{ Measured level of wax content $(\%)$} \\
\cline { 2 - 3 } & Before Adding the Flour & After Adding the Flour \\
\hline 5 & 5.27 & 4.58 \\
5 & 4.92 & 4.75 \\
5 & 4.92 & 4.84 \\
\hline
\end{tabular}

The precision test was conducted in order to find out whather the developed method will still get the similar result if it is repeated. The determination of this test was done on selfmade gorengan which is fried in hot cooking oil containing wax concentration of $0 \%, 5 \%$ and $10 \%$, and then, the discoloration was observed by using univariate analysis on Photometrix ${ }^{\circledR}$ application. The measured pixel value on gorengan with no wax content shows a range of values from 95 to 102.5 pixels. This means that wax concentration measured on K1 quadrant shows $0 \%$ of wax concentration or less than the detection limit. The measured pixel value on gorengan with $5 \%$ and $10 \%$ of wax concentration are on a range of 124-128 pixels and 133-141 pixels which shows quadrant of $\mathrm{K} 2$ and $\mathrm{K} 3$. The \%RSD obtained in $0 \%, 5 \%$ and $10 \%$ of wax concentration is $1.1 \% ; 2.4 \%$ showing that the analytical method has good degree of precision (Table II).

Selectivity is determined by comparing between cooking oil containing $5 \%$ of wax and fried dough. The flour selected as the matrix is potential to interfere the analysis result because flour is generally used in making gorengan. The measurement result is presented in Table III. The result of statistial data processing shows that the data is normally distributed with a significance value of 0.143 . The result of one-way ANOVA analysis with $5 \%$ of $\alpha$ presents that the flour does not significantly show different result with $p$-value of 0.99 . It can be concluded that adding the flour as matrix cannot significantly interfere the analysis. The developed method is selective enough to identify wax content in gorengan dough.

\section{Application Method on Gorengan Sample}

Implementation of multivariate analysis on Photometrix ${ }^{\circledR}$ application on smartphone is used to detect wax content on five different gorengan namely fried tofu, fried tempe, fried banana, fried sweet potato and bakwan (vegetables fritter snack). The gorengan samples were randomly picked in the market. This examination aims to identify the classifications among test samples. If the test sample containing wax, it will be classified on the similar quadrant. From the five samples that had been analyzed, the sample of fried tempe shows $5 \%$ and $10 \%$ of wax 
concentration which is indicated on quadrants of $\mathrm{K} 2$ and $\mathrm{K} 3$ (Figure 3). The test result is in accordance with the research conducted by Helfer and other researchers who provide the ability of Photometrix ${ }^{\circledR}$ application in grouping banknotes based on their color from different countries based on the paper used (Helfer et al. 2017). As a comparative method, TLC test was conducted and it showed that there were spots on the sample of fried tempe with $\mathrm{Rf}$ value of 0.52 and 0.50 which is equivalent to $\mathrm{Rf}$ value of the sample of cooking oil which is deliberately added wax. This $\mathrm{Rf}$ value is almost similar with the $\mathrm{Rf}$ value of wax sample analyzed by the similar TLC system. Therefore, it can be ascertained that the spots appearing in the sample are wax spots. While the samples other than the sample of fried tempe do not show spots which indicate that the sample tested does not contain wax. The result shows that smartphone can be used to detect wax content on gorengan. Smartphone analysis method using Photometrix ${ }^{\circledR}$ application needs further development on the reagent and color image data processing in order to be used to detect wax content on lower concentration.

\section{CONCLUSION}

The wax content on gorengan can be detected by using Photometrix ${ }^{\circledR}$ application on smartphone. Parameter performance of the developed method shows good result with the correlation coefficient value $(r)$ of 0.9537 and it is accurate with \% RSD value less than $3 \%$. This can be implemented to detect the wax content on gorengan.

\section{REFERENCES}

Bernabé-Pineda, M., Ramírez-Silva, M.T., Romero-Romo, M., González-Vergara, E., and Rojas-Hernández, A. 2004. Determination of acidity constants of curcumin in aqueous solution and apparent rate constant of its decomposition. Spectrochimica Acta Part A: Molecular and Biomolecular Spectroscopy, 60 (5), 1091-1097.

Chalid, S.Y., Muawanah, A., and Jubaedah, I., 2008. Analisa radikal bebas pada minyak goreng pedagang gorengan kaki lima. Jurnal Kimia VALENSI, 1 (2), 82-86.

Chen, J., Zhang, J., and Li, H., 2004. Determining the wax content of crude oils by using differential scanning calorimetry. Thermochimica Acta, 410 (1), 23-26.

Derudi, M., Gelosa, S., Sliepcevich, A., Cattaneo, A., Cavallo, D., Rota, R., and Nano, G., 2014. Emission of air pollutants from burning candles with different composition in indoor environments. Environmental Science and Pollution Research International, 21 (6), 4320-4330.

Dong, C., Wang, Z., Zhang, Y., Ma, X., Iqbal, M.Z., Miao, L., Zhou, Z., Shen, Z., and $\mathrm{Wu}$, A., 2017. High-performance colorimetric detection of thiosulfate by using silver nanoparticles for smartphone-based analysis. ACS sensors, 2 (8), 1152-1159.

Griffis, L.C., Twerdok, L.E., Francke-Carroll, S., Biles, R.W., Schroeder, R.E., Bolte, H., Faust, H., Hall, W.C., and Rojko, J., 2010. Comparative 90-day dietary study of paraffin wax in Fischer-344 and Sprague-Dawley rats. Food and Chemical Toxicology: An International Journal Published for the British Industrial Biological Research Association, 48 (1), 363-372.

Helfer, G.A., Magnus, V.S., Böck, F.C., Teichmann, A., Ferrão, M.F., Costa, A.B. da, Helfer, G.A., Magnus, V.S., Böck, F.C., Teichmann, A., Ferrão, M.F., and Costa, A.B. da, 2017. PhotoMetrix: An Application for Univariate Calibration and Principal Components Analysis Using Colorimetry on Mobile Devices. Journal of the Brazilian Chemical Society, 28 (2), 328-335.

Jung, Y., Kim, J., Awofeso, O., Kim, H., Regnier, F., and Bae, E., 2015. Smartphone-based colorimetric analysis for detection of saliva alcohol concentration. Applied optics, 54 (31), 9183-9189. 
Jungreis, E., 2004. Spot Test Analysis. Encyclopedia of Analytical Chemistry.

Kök, M., Letoffe, J., and Claudy, P., 2007. Comparative methods in the determination of wax content and pour points of crude oils. Journal of Thermal Analysis and Calorimetry, 90 (3), 827-831.

Lu, X., Kalman, B., and Redelius, P., 2008. A new test method for determination of wax content in crude oils, residues and bitumens. Fuel, 87 (8-9), 1543-1551.

Moreau, R.A., Kohout, K., and Singh, V., 2002. Temperature-enhanced alumina HPLC method for the analysis of wax esters, sterol esters, and methyl esters. Lipids, 37 (12), 1201-1204.

Ngom, B., Guo, Y., Wang, X., and Bi, D., 2010. Development and application of lateral flow test strip technology for detection of infectious agents and chemical contaminants: a review. Analytical and Bioanalytical Chemistry, 397 (3), 1113-1135.

Palou, A., Cruz, J., Blanco, M., Larraz, R., Frontela, J., Bengoechea, C.M., González, J.M., and Alcalà, M., 2014. Characterization of the composition of paraffin waxes on industrial applications. Energy \& Fuels, 28 (2), 956-963.

Rezaei, K., Wang, T., and Johnson, L.A., 2002. Hydrogenated vegetable oils as candle wax. Journal of the American Oil Chemists' Society, 79 (12), 12411247.
Sølling, A.S.K., Tougaard, B., Harsløf, T., Langdahl, B., Kongsbak Brockstedt, H., Byg, K.-E., Ivarsen, P., Karstoft Ystrøm, I., Holden Mose, F., Lissel Isaksson, G., Steen Svarer Hansen, M., Nagarajah, S., Ejersted, C., Bendstrup, E., and Rejnmark, L., 2018. Nonparathyroid hypercalcemia associated with paraffin oil injection in 12 younger male bodybuilders. European Journal of Endocrinology, EJE-180051.

Sutrisno, Y.G., Khoirunnisa, S., Agustien, D.S., Karyati, E., Fasya, N., and Wasito, H., 2017. Qualitative Analysis of Test Strip for Sildenafil Citrate with Some Combinations Reagen in Cellulosa Paper Membran. Jurnal Ilmu Kefarmasian Indonesia, 15 (2), 9-14.

$\mathrm{Wu}$, Y., Boonloed, A., Sleszynski, N., Koesdjojo, M., Armstrong, C., Bracha, S., and Remcho, V.T., 2015. Clinical chemistry measurements with commercially available test slides on a smartphone platform: Colorimetric determination of glucose and urea. Clinica Chimica Acta, 448, 133-138.

Yang, X., Wang, Y., Liu, W., Zhang, Y., Zheng, F., Wang, S., Zhang, D., and Wang, J., 2016. A portable system for on-site quantification of formaldehyde in air based on G-quadruplex halves coupled with a smartphone reader. Biosensors and Bioelectronics, 75, 4854. 